\title{
Impact of active tourism on economic development - example of the Fruška Gora National park (Vojvodina, North Serbia)
}

\author{
Mirjana Penić ${ }^{A *}$, Miloš Dragosavac ${ }^{B}$, Aleksandra Vujko $^{B}$, Snežana Besermenji ${ }^{A}$ \\ Received: May 19, 2016 | Revised: August 25, 2016 | Accepted: September 11, 2016
}

\begin{abstract}
Over the past few years, there has been intensified research about active tourism development in the area of Fruška Gora National Park and its impact on economic and business development, namely, potential development of certain economic categories within the given area and the gravitating area of the national park. Based on this, the main hypothesis has been formulated. It explains that more intensive development of tourism trends (for which favourable preconditions exist) in Fruška Gora National Park have positive impact on the overall economic development of the gravitation zone, which includes the area of the city of Novi Sad (Serbia). The primary goal of this study was to investigate the attitudes of respondents about Fruška Gora National Park as a tourism resource suitable for development of active tourism, and to show existing and potential impacts of the economic categories. The survey was conducted in prominent cycling, hiking and equestrian clubs in the city of Novi Sad, and on a random sample of the residents of Novi Sad (the sample of 303 respondents). The data were processed with the SPSS program (version 17.0). To determine the frequency of specific deviations chi-square test was used.

Keywords: active tourism, economic development, Fruška Gora National Park, Vojvodina, Serbia
\end{abstract}

\section{Introduction}

In the comprehensive economic development tourism is recognized as an important economic activity, an important export product and engine for growth of overall economic development. Its important propulsive and integrative character and role of multiplier, inductor and accelerator of global economic trends have been reduced to a minimum in Vojvodina, which seems to be a huge misconception, since tourism in this area can make a major contribution to overall economic development. The previous development of tourism in the region was affected by overall socio-economic development in Serbia. There are assumptions that the intensive tourism development (all tourism products) in Fruška Gora National Park may induce positive impact through a series of direct and indirect economic changes within certain categories (Sterrer, 1993; Gajić, 2010; Gajić, Ivkov, 2010), not only in the area observed but also within the whole gravitating area, in this case, city of Novi Sad. This is the starting point in the design of the main hypotheses. It has been found that there are preconditions to turn this area into a large-scale tourism development, and thus achieve visible economic effects. Advantageous geographical position with morphological, hydrological, climatological, biogeographical and anthropogeographical values are important for the development of tourism. However, the number of tourists and their overnight stays, foreign tourist especially, and achieved economic and social effects of tourism, sug-

\footnotetext{
A Department of Geography, Tourism and Hotel Menagement, Faculty of Science, University of Novi Sad, Trg Dositeja Obradovića 3, 21000 Novi Sad, Serbia; penicns@yahoo.com

B Novi Sad Business School, Vladimira Perica Valtera 4, 21000 Novi Sad, Serbia; aleksandravujko@yahoo.com

* Corresponding author: Mirjana Penić, e-mail: penicns@yahoo.com
} 
gest that all these benefits are underused (Van Den Bergh, 1993; Lee, Chang, 2008; Nunkoo, Smith, 2013). However, the right way to escape anonymity and to launch a permanent massification of tourism supply with the aim of prosperous business and economic development has not been found yet. The authors estimate that sports and recreational tourism are actually associations for the development of tourism in Fruška Gora National Park. Other forms of tourism are minimally represented. Assuming the interest in this form of tourism in Fruška Gora National Park, the authors have investigated the real percentage of tourist traffic, and the percentage of satisfaction with all segments of tourism that may be crucial for the development of this type of tourist movement, and finally the data on the total tourist turnover with certain assumption that point out to the economic development of that area and the dispersion area of the city of Novi Sad. In this sense, the primary goal of the study was to indicate the current status, in the best way possible, and the possible effects that active development of special forms of tourism trends would have in Fruška Gora National Park. The purpose of this paper is that the observed connectivity is utilised for production of specific innovative projects that would develop the system of internal and cross-border partnerships (Barnett, 2004; Vujko, Plavša, 2014; Vujko, Gajić, 2014) that would contribute to sustainable development (Hohl, Tisdell, 1995; King, Slesser, 1995; Mihalic, 2000; Andereck, Nyaupane, 2011; Bramwell, 2011), encouraging entrepreneurship and a growing number of users in tourism (Nunkoo, Ramkissoon, 2011; Vujko, 2012; Nunkoo, Gursoy, 2012; Nunkoo, Ramkissoon, 2012). For the purposes of this research, a survey was used as a method, whereby 350 questionnaires were distributed and 303 of them were analyzed. This analysis leads to the confirmation of the given hypothesis and refutation of other hypotheses. The SPSS program, version 17.0, and T-square test were used. In addition to the research data, the authors used the available statistical and other secondary documentation.

\section{Literature review}

To determine the level of development of tourism in each region, it is necessary to observe the mentioned rational and irrational factors (Riera-Font, 2000), which represent a demanding and full survey research, pertaining to both economic and social sciences. What we have primarily explored is based on the existing development of infrastructure and development of tourism industry in Fruška Gora National Park. These factors will continue providing a positive economic effect, referring to certain indicators of development. Tourism products from these regions were perceived as part of the regional tourism offer of the national park. They represent the ultimate result of interrelated and coordinated procedures and related harmonized procedures inside of which they already perform quantitative and qualitative transformation of the tourism resources of the area to its tourist value; in fact, in its regional tourism supply, and then in general tourist product. Factors that are not in the chain factors of regional tourism supply or in the general tourism product are not under the influence of tourism policy measures. Most theorists who deal with themes of tourism development in the form of massive and thematic forms of tourism trends, point out that this development is in favour of regional (business and economic) development (Richi, Hall, 1999, Hayward, 2001, Hudson, 2003; Weed, Bull, 2004; Torkildsen 2005, Weed, 2008; Matthew, 2009, Downward, et al, 2009, Vujko, Plavša, 2010; Vujko, 2011; Morakabati, et al, 2012). According to research conducted in UK (Weed, Bull, 2004; Weed, 2008) and Serbia (Vujko, 2011; Vujko, 2012) it can be seen that the respondents in sport and recreational tourism, picnic tourism and excursion tourism, spent most on thematic maps and guides, accommodation, and specialized service tasks. This is particularly interesting because it is possible to come to the conclusion that the investment in material base of tourism will soon pay off. Development of sports and recreational tourism in the national park would have longterm positive economic effects. These effects would greatly contribute to the revival of rural areas in the region and encourage the economic development of the city of Novi Sad. Sports and recreational tourists are not just accidental tourists. They enjoy the offered experience and are always gladly back in destinations where their needs have been satisfied. Benefits from the development of sports and recreational tourism would be more far-reaching than they are now, and natural and cultural resources would be equally developed (Standeven, Knop, 1999; Cutumisu, Cottrell, 2004; Vujko, 2012). Primarily, it would also mean the development of Fruška Gora National Park and its dispersion area. Tourism can contribute to achieving the objectives of development policy (balance in economic relations, increasing employment, regional development, etc.), but only if the choice of measures to guide development of tourism are not neglected phases of economic development, legal development and particularity of this activity, demand, quality factors and the development costs of such a policy. Otherwise the growth of tourism in quantitative terms may indicate the achievement of the objectives of development policy, and does not contribute to the overall stabilization of the economy (Blake, et al, 2006; Besana, Bagnasco, 2014). Tourism only in interdepend- 
ence and in line with the level of development of other activities can generate optimal results (Blake, et al, 2006; Lee, Chang, 2008). This is very important because the current orientation of the industrialization neglects not only industrial production orientation to the tourist market and building material basis for catering, tourism development, but more importantly, for agriculture, transport and other infrastructure, especially in tourist areas. Tourism as an economic activity becomes more and more important place in the economy, and is characterized by the addition of direct and indirect impact of development on a number of other industries (Vujko, Gajić, 2014). This gives rise to difficulties in precise determination of its actual contribution to the economic and social development. However, inadequate evaluation of natural and anthropogenic values, poor economic structure, and inadequate infrastructure construction slow the growth of tourism. Tourism is defined as part of the national economy that supplies the tourists who visit the site outside the place of work and residence. This sector undoubtedly contributes to the economic development of the country, but also breaks the negative image that foreign tourists have about Serbia $(\mathrm{Vu}-$ jko, Gajić, 2014). However, what differentiates tourism from other economic activities is that it never appears as an independent activity, and there is no possibility for the determination of the tourism industry as a separate and independent entity. As a result of tourist spending in a particular destination, there is the impact of tourism on the economy (Nunkoo, Ramkissoon, 2012). First, it is necessary to point out the direct and indirect effects, but what should not be left out is the fact that there are the multiplier effects of tourism. Direct impact is the impact which is noticeable in the social product and national income of specific countries because tourism can be considered as their creator. In addition, tourism entails the development of other industries and activities such as catering, trade, transportation, sports and other. An important role of this activity is the increased engagement of the working age population of all structures, since workforce is hired in other activities related to tourism.

\section{Research methodology}

The research was a combination of quantitative methods (statistics and web analysis) and qualitative methods (interviews, discussion and written documents). Bibliographic speculative was used in the phase of defining the theoretical framework, and descriptive method for data processing and results interpretation. The first part of the paper is the field research and data collection by direct examination conducted in three cycling clubs from the city of Novi Sad ("Vojvodina", "Elite" and "Velo"), two mountaineering associations from the city of Novi Sad ("Železničar" and "Poštar"), the equestrian club "Petras" in Petrovaradin, and among accidental tourists. The research was a part of a project that was conducted in order to test the hypothesis that Fruška Gora National Park has the resources to develop certain forms of tourism trends. The questionnaire was made in 350 copies, and the sample of 303 respondents was divided into four groups: cyclists, hikers, off-road riders and accidental tourists. The survey was conducted between May and August 2014, and the questionnaire consisted of 30 questions grouped into independent and dependent variables. Independent variable is a group of questions that are related to gender, family status and age structure. In the second part of the data processing and analysis of the dependent variables were completed. The variables reflect the opinion of the respondents about the advantage of a particular form of activity, as well as satisfaction with the quality of the current situation. The assessment of the current situation and possibilities of tourism impact on the economic development of that area resulted in another field survey and analyses were carried out on the basis of data obtained from Statistical Office of the Republic of Serbia. However, there is still no "unique registration of tourism operations" in Serbia about the number of tourists and overnight stays in various facilities in Fruška Gora National Park, the data are based on subjective evaluations of service providers about surveyed visitors and they are relatively approximate to the real values. The obtained data were analyzed by appropriate statistical methods, both descriptive and comparative, enabling the explication of the research results and drawing certain conclusions. One form of the analysis of the data was the chi-square test (Pearson Chi-Square Test). It was used to determine whether a received (observed) frequency (responses), deviate from the frequencies that were expected. This test aimed to check if there is a connection among these four groups of respondents and the probability of connection. In practice we always start from the premise that there are certain values of the difference in responses. In order to detect differences in the responses measured on the basis of statistically significant differences in the distribution of the dependent variable in relation to independent, and statistically significant differences those for which $\mathrm{p}<0,05$ are taken. The study started from the main hypothesis $\mathrm{H}$ : intensive development of tourism trends (for which the preconditions exist) in Fruška Gora National Park positively affect the overall economic development of the dispersion zone, which includes the area of Novi Sad. Under this hypothesis certain lower-level hypothe- 


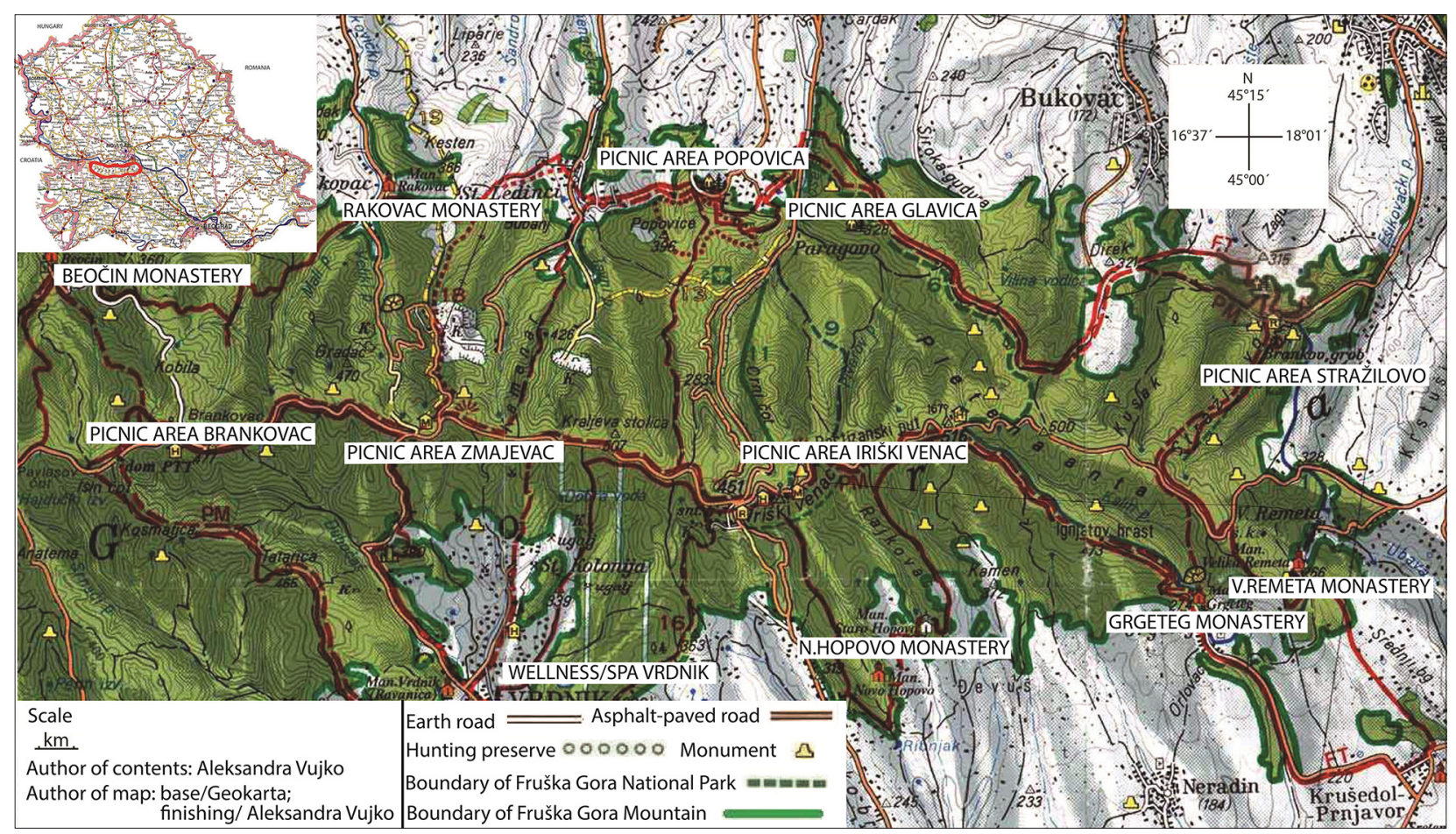

Figure 1. The observed area in the eastern and central parts of the Fruška Gora National Park.

Source: base Geokarta-adapted by A. Vujko

ses were set: $h_{1}$ - there is interest in a number of activities that are practiced as part of the tourism offer in Fruška Gora National Park; h2 - the national park area is suitable for the development of special interest tourism, for which the preconditions exist, $\mathrm{h}_{3}$ - there are all the conditions provided for active tourism development in the national park; $\mathrm{h}_{4}$ - tourists, namely the respondents of sports and recreational forms of motion are satisfied with all aspects of supply that is available to them and the need for this type of movement, $\mathrm{h} 5$ - tourism has a positive effect on certain economic categories; h6 - tourism development in the national park is a prerequisite for increasing tourist traffic in dispersion zone i.e. the city of Novi Sad.

\section{Results and discussion}

Out of the 350 questionnaires, 303 were analysed, which makes a fairly representative sample. The respondents in the survey (Table 1) were visitors to the national park in the following structure: cyclists (22.8\%), hikers (16.6\%), off-road riders (14.2\%), and accidental tourists $(45.4 \%)$. Regarding the age structure of the visitors, the survey included $56.6 \%$ of male and $43.4 \%$ of female population. The largest percentage of them $59.6 \%$ was in the age group $25-35$, followed by $14.4 \%$ in the age group $16-25$, and the lowest percentage of the respondents in the age group $35-45(4.1 \%)$, followed by those aged 15 (4.8\%), and over 56 (9.6\%).

The results showed that all the respondents answered that the national park is a suitable area for de- velopment of sports and recreational tourism (Table 2). Out of the total number of respondents of all structures, $35.8 \%$ responded that the national park is suitable for the development of all activities, and $25.3 \%$ that the national park is the most suitable for the development of hiking, followed by $21.5 \%$ of those who responded that the national park is suitable for the development of cycling, and $16.7 \%$ for the development of horseback riding. Likewise, the fact is that in the beginning it showed that there are tendencies of massive development of sports and recreational tourism and there were only $0.7 \%$ of those who believed that this National Park is not conducive to the development of any of these activities. After examining the same table it can be concluded that there is a statistically significant difference in responses, which is $\mathrm{p}=$ o.0oo. By analyzing this data it can be concluded that the cause is found in the subjective difference of subjects. In fact, some groups provided answers accord-

Table 1. Sample structure

\begin{tabular}{|l|l|c|c|}
\hline \multicolumn{2}{|c|}{} & Frequencies & $\%$ \\
\hline \multirow{4}{*}{$\begin{array}{l}\text { Valid } \\
\text { data }\end{array}$} & Cyclists & 69 & 22.8 \\
\cline { 2 - 4 } & Hikers & 50 & 16.6 \\
\cline { 2 - 4 } & Off-road Riders & 43 & 14.2 \\
\cline { 2 - 4 } & Accidental tourists & 137 & 45.4 \\
\cline { 2 - 4 } & Total & 299 & 99.0 \\
\hline Missing & \multicolumn{2}{|c|}{3} & 1.0 \\
\hline Total & 302 & 100 \\
\hline
\end{tabular}

Source: authors research 
Table 2. Features of Fruška Gora National Park for certain activities

\begin{tabular}{|c|c|c|c|c|c|c|}
\hline & Bicycling & Mountaineering & Riding & All & None of the above & Total \\
\hline \multirow{2}{*}{ Cyclists } & 20 & 28 & 10 & 10 & 0 & 68 \\
\hline & $6.8 \%$ & $9.6 \%$ & $3.4 \%$ & $3.4 \%$ & $0 \%$ & $23.2 \%$ \\
\hline \multirow{2}{*}{ Hikers } & 15 & 24 & 2 & 7 & 0 & 48 \\
\hline & $5.1 \%$ & $8.2 \%$ & $0.7 \%$ & $2.4 \%$ & $0 \%$ & $16.4 \%$ \\
\hline \multirow{2}{*}{ Off-road Riders } & 7 & 8 & 23 & 2 & 0 & 40 \\
\hline & $2.4 \%$ & $2.7 \%$ & $7.8 \%$ & $0.7 \%$ & $0 \%$ & $13.7 \%$ \\
\hline \multirow{2}{*}{$\begin{array}{l}\text { Accidental } \\
\text { tourists }\end{array}$} & 21 & 14 & 14 & 86 & 2 & 137 \\
\hline & $7.2 \%$ & $4.8 \%$ & $4.8 \%$ & $29.4 \%$ & $0.7 \%$ & $46.8 \%$ \\
\hline \multirow{2}{*}{ Total } & 63 & 74 & 49 & 105 & 2 & 293 \\
\hline & $21.5 \%$ & $25.3 \%$ & $16.7 \%$ & $35.8 \%$ & $0.7 \%$ & $100.0 \%$ \\
\hline \multirow{2}{*}{\multicolumn{2}{|c|}{ Pearson Chi-Square Test }} & Value & $d f$ & & \multicolumn{2}{|c|}{ Statistical significance $(p)$} \\
\hline & & 141.070 & 12 & & \multicolumn{2}{|c|}{0.000} \\
\hline
\end{tabular}

Source: authors research

ing to their preferences (e.g. cyclists mostly responded that the national park is a suitable space for the development of cycling, hikers for hiking and horseback riders for off-road riding). The analysis of the data confirmed hypothesis 2 (h2), which states that Fruška Gora National Park is an area suitable for the development of certain activities.

The results presented in Table 3 show the period of time that respondents spent in the national park. This issue is important for two reasons: because it implies the knowledge of the area and because the respondents confirmed their "affiliation" to the national park and the area for the weekend excursion tourism. There is the highest percentage of those who occasionally come to this region (75.6\%), whereas there is the smallest percentage of those who visit it daily (only $10.7 \%)$. After examining the same table it can be concluded that there is a statistically significant difference in responses, which is $\mathrm{p}=0.000$.
After examining the Table 4 it can be concluded that the majority of respondents declared dissatisfaction with the existing tourism infrastructure and material base. According to the obtained results, the hypothesis $4\left(\mathrm{~h}_{4}\right)$ is totally refuted, which states that the respondents are satisfied with all segments of supply that are provided for their activities. The results were surprisingly negative. Specifically, $93.2 \%$ of them were completely dissatisfied with the offer of accommodation, the existing signalling pathways provided for their activities (only $6.8 \%$ of satisfied respondents). On that occasion, the responses of different respondent structures do not differ to a great extent, so a statistically significant difference was not noticed. In order to obtain a clearer picture of the shortcomings of the quality of tourism infrastructure and tourism superstructure, the respondents were asked about the disadvantages.

Table 3. Time that respondents spent in the National Park

\begin{tabular}{|c|c|c|c|c|c|}
\hline & Periodically & Every Day & When I have time & Often & Total \\
\hline \multirow{2}{*}{ Cyclists } & 21 & 4 & 17 & 25 & 67 \\
\hline & $7.2 \%$ & $1.4 \%$ & $5.8 \%$ & $8.6 \%$ & $23.0 \%$ \\
\hline \multirow{2}{*}{ Hikers } & 28 & 2 & 11 & 8 & 49 \\
\hline & $9.6 \%$ & $0.7 \%$ & $3.8 \%$ & $2.7 \%$ & $16.8 \%$ \\
\hline \multirow{2}{*}{ Off-road riders } & 18 & 4 & 13 & 5 & 40 \\
\hline & $6.2 \%$ & $1.4 \%$ & $4.5 \%$ & $1.7 \%$ & $13.7 \%$ \\
\hline \multirow{2}{*}{ Accidental tourist } & 75 & 21 & 37 & 2 & 135 \\
\hline & $25.8 \%$ & $7.2 \%$ & $12.7 \%$ & $0.7 \%$ & $46.4 \%$ \\
\hline \multirow{2}{*}{ Total } & 142 & 31 & 78 & 40 & 291 \\
\hline & $48.8 \%$ & $10.7 \%$ & $26.8 \%$ & $13.7 \%$ & $100 \%$ \\
\hline \multirow{2}{*}{\multicolumn{2}{|c|}{ Pearson Chi-Square Test }} & Value & $\mathrm{df}$ & \multicolumn{2}{|c|}{ Statistical significance $(p)$} \\
\hline & & 55.720 & 9 & \multicolumn{2}{|c|}{0.000} \\
\hline
\end{tabular}

Source: authors research 
Table 4. Satisfaction with the quality of existing roads, signs and accommodation capacity

\begin{tabular}{|l|c|c|c|c|}
\hline \multirow{3}{*}{ Cyclists } & Yes & No & I do not know & Total \\
\hline \multirow{3}{*}{ Hikers } & 1 & 66 & 1 & 68 \\
\cline { 2 - 5 } & $0.3 \%$ & $22.4 \%$ & $0.3 \%$ & $23.1 \%$ \\
\hline \multirow{3}{*}{ Off-road riders } & 1 & 39 & 7 & $16 \%$ \\
\cline { 2 - 5 } & $0.3 \%$ & $13.3 \%$ & 7 & 42 \\
\hline \multirow{3}{*}{ Accidental tourists } & 11 & 24 & $2.4 \%$ & $14.3 \%$ \\
\cline { 2 - 5 } & $3.7 \%$ & $8.2 \%$ & $21.4 \%$ & 137 \\
\hline \multirow{2}{*}{ Total } & 7 & 67 & 78 & $29.6 \%$ \\
\hline \multirow{2}{*}{$\begin{array}{l}\text { Pearson Chi-Square } \\
\text { Test }\end{array}$} & $2.4 \%$ & $22.8 \%$ & $26.5 \%$ & $100 \%$ \\
\cline { 2 - 5 } & $8.8 \%$ & 196 & Statistical significance (p) \\
\hline
\end{tabular}

Source: authors research

Table 5 shows the largest gap in the opinion of respondents: no marked trails and lack of adequate signage $(22.2 \%)$. Improving the quality of tourist supply of the given area is the future of its development. Primarily, the focus was on the reconstruction and renovation of restaurants, and building of the new ones (which has already started, but mainly in the area of Novi Sad) based on international standards and regulations. Moreover, the introduction of new technologies in serving and reservations, the introduction of standards for travel agencies and other tour operators, etc. Tourism contributes significantly to diminishing global disturbances for the national economy. The respondents were also dissatisfied with the offer of thematic maps and guides that are essential to their activities; $19.5 \%$ of them pointed out the lack of this segment as well. Overall $10.8 \%$ of respondents considered the accommodation facilities inadequate in the current offer. Also, there were respondents who pointed out the need of investing in info centres, service stations and stops (13.8\%), whereas $15.8 \%$ of them considered that transportation and rental equipment should improve. After examining the same table it can be concluded that there is a statistically significant difference in responses, which is $\mathrm{p}=0.000$. Thus, there is the evidence that interest in certain tourist movement in Fruška Gora National Park exists to some extent, but there are a few conditions that would fully meet all their needs (thus confirming hypothesis $h 1$ and disconfirming hypothesis $h_{3}$ ).

The next step in the paper is to observe to what extent this form of tourism may be directly or indi-

Table 5. Disadvantages of the National Park as convenient and attractive destination for sports and recreational tourism

\begin{tabular}{|c|c|c|c|c|c|c|c|}
\hline & $\begin{array}{l}\text { Marked } \\
\text { trails and } \\
\text { tourist signs }\end{array}$ & $\begin{array}{l}\text { Thematic } \\
\text { maps and } \\
\text { guides }\end{array}$ & $\begin{array}{c}\text { Specialized } \\
\text { accommodation } \\
\text { facilities }\end{array}$ & $\begin{array}{l}\text { Information } \\
\text { centres and other } \\
\text { service stations } \\
\text { and stops }\end{array}$ & $\begin{array}{l}\text { Ability to } \\
\text { transport } \\
\text { equipment } \\
\text { and rental }\end{array}$ & $\begin{array}{c}\text { All of the } \\
\text { above }\end{array}$ & Total \\
\hline \multirow{2}{*}{ Cyclists } & 23 & 21 & 4 & 3 & 11 & 6 & 68 \\
\hline & $7.7 \%$ & $7.1 \%$ & $1.3 \%$ & $1.0 \%$ & $3.7 \%$ & $2.0 \%$ & $22.9 \%$ \\
\hline \multirow{2}{*}{ Hikers } & 16 & 11 & 5 & 5 & 4 & 9 & 50 \\
\hline & $5.4 \%$ & $3.7 \%$ & $1.7 \%$ & $1.7 \%$ & $1.3 \%$ & $3.0 \%$ & $16.8 \%$ \\
\hline \multirow{2}{*}{$\begin{array}{l}\text { Off-road } \\
\text { riders }\end{array}$} & 1 & 6 & 6 & 6 & 7 & 16 & 42 \\
\hline & $0.3 \%$ & $2.0 \%$ & $2.0 \%$ & $2.0 \%$ & $2.4 \%$ & $5.4 \%$ & $14.1 \%$ \\
\hline \multirow{2}{*}{$\begin{array}{l}\text { Accidental } \\
\text { tourists }\end{array}$} & 26 & 20 & 17 & 27 & 25 & 22 & 137 \\
\hline & $8.8 \%$ & $6.7 \%$ & $5.7 \%$ & $9.1 \%$ & $8.4 \%$ & $7.4 \%$ & $46.1 \%$ \\
\hline \multirow{2}{*}{ Total } & 66 & 58 & 32 & 41 & 47 & 53 & 297 \\
\hline & $22.2 \%$ & $19.5 \%$ & $10.8 \%$ & $13.8 \%$ & $15.8 \%$ & $17.8 \%$ & $100 \%$ \\
\hline \multirow{2}{*}{\multicolumn{3}{|c|}{ Pearson Chi-Square Test }} & Value & $\mathrm{df}$ & \multicolumn{3}{|c|}{ Statistical significance $(p)$} \\
\hline & & & 47.460 & 15 & \multicolumn{3}{|c|}{0.000} \\
\hline
\end{tabular}

Source: authors research 
rectly affecting certain economic segments (h5) and to what extent the development of tourism in Fruška Gora National Park could have an impact on tourism operations in Novi Sad (h6). Most visited destinations in Fruška Gora National Park between 2013 and 2015 were Iriški venac and Irig. Bearing in mind that there are no data on the structure of sports tourists, the current data received could be only partially utilized, which means that without official data (a key issue of registered tourists visit), but owing to the characteristics of the destination and the structure of the site, it may be assumed that for some tourists sports and recreational activities were important. The development of sports and recreational tourism, in addition to direct economic impact in the National Park, also includes indirect impact. The expansion of supply would affect the arrangement of space for relaxation purposes and provision of sanitary and catering services that would enable the opening of many jobs and yield benefits for the local population (Barnett, 2004). The expected benefits of such a system of cycle paths would be the utilisation of these paths for other, complementary forms of tourism. Furthermore, the networking would imply continuous development of the whole area (particularly the connections with the Republic of Croatia and the continuation of cycle paths in Vukovar-Srem county and Osijek-Baranja county), and the connection to the network of cycle paths (Croatia, Slovenia, Hungary, Austria), would result in European cycling transversal that would create other tourist products (Barnett, 2004; Vujko, Plavša, 2011; Vujko, Gajić, 2014). This information confirms the hypothesis h5. According to its character tourism falls within the group of activities with the permanent basis that allows immediate engagement of the working age population from all social, age and sex groups, and with various levels education. The polyvalent character of tourism services opens a wide scope for further employment of the whole range of other economic and non-economic activities, so that the effect of tourism as a factor in employment is reflected in the numerous segments of social, economic and social structures. When the number of employees in the tourism sector (hotel and catering) in Vojvodina is added to all those who participate in other ac-
Table 6. Registered tourists in Fruška Gora National Park (2013 - 2015)

\begin{tabular}{|c|c|c|}
\hline Year 2013. & Tourist arrivals & Overnight stays \\
\hline January & 1,082 & 5,101 \\
\hline February & 1,252 & 5,400 \\
\hline March & 1,348 & 5,783 \\
\hline April & 1,741 & 6,543 \\
\hline May & 1,563 & 7,731 \\
\hline June & 1,502 & 7,456 \\
\hline July & 1,535 & 8,379 \\
\hline August & 1,686 & 8,591 \\
\hline September & 1,352 & 7,229 \\
\hline October & 1,154 & 6,455 \\
\hline November & 1,251 & 5,379 \\
\hline December & 1,120 & 2,931 \\
\hline Year 2014. & Tourist arrivals & Overnight stays \\
\hline January & 900 & 3,688 \\
\hline February & 961 & 3,979 \\
\hline March & 1,084 & 4,433 \\
\hline April & 1,115 & 4,529 \\
\hline May & 1,184 & 5,805 \\
\hline June & 1,263 & 5,342 \\
\hline July & 1,202 & 6,153 \\
\hline August & 1,566 & 6,638 \\
\hline September & 1,237 & 6,362 \\
\hline October & 1,233 & 4,838 \\
\hline November & 1,384 & 4,391 \\
\hline December & 1,352 & 3,586 \\
\hline Year 2015. & Tourist arrivals & Overnight stays \\
\hline January & 1,127 & 3,474 \\
\hline February & 1,022 & 3,679 \\
\hline March & 1,153 & 4,460 \\
\hline April & 1,279 & 3,166 \\
\hline May & 1,669 & 5,465 \\
\hline June & 1,514 & 6,666 \\
\hline July & 1,599 & 6,604 \\
\hline August & 1,914 & 8,268 \\
\hline September & 1,652 & 6,412 \\
\hline October & 1,748 & 5,636 \\
\hline November & 1,716 & 5,215 \\
\hline December & - & - \\
\hline
\end{tabular}

Source: The National Bureau of Statistics, 2016.

Table 7. Employment in legal entities in the tourism sector in the city of Novi Sad in 2015

\begin{tabular}{|l|l|}
\hline The tourism sector & Number of employees \\
\hline Accommodation and food & 4630 \\
\hline Arts, entertainment and recreation & 3485 \\
\hline Activities of travel agents, tour operators, reservation services and other services & 2899 \\
\hline Total: & 11014 \\
\hline
\end{tabular}

Source: The National Bureau of Statistics, 2016 
tivities either partially or completely - in providing various kinds of tourist services (and thus obtain personal earnings) only then there will be an insight into the overall effects of development tourism on employment of the population. This should join the so-called cottage industry based on accommodation and food, and also existentially related to tourism as a source of income. However, in the city of Novi Sad, employment in tourism now is relatively on a low level compared to other sectors. Tourism engagement of the Province of Vojvodina has been on unsatisfactory lev$\mathrm{el}$, and so there is no impression that tourism is among primary sectors, although it has been mentioned in the plans of development. The data in Table 7 indicate the percentage of the population employment in the tourism sector and general services. It is observed that the expenditure on the development of tourism in Fruška Gora National Park is minimal, and there is no significant impact on the development of the economy of Novi Sad. The interests are recognized, but they require substantial investment in infrastructure as part of tourism, and overall system management and marketing in order to achieve significant results. Given the current situation and the results that have been reached regarding the turnover, it appears that the hypothesis h6 is actually partially true, and that there is a possibility that the development of tourism in Fruška Gora National Park may influence the tourism of Novi Sad, and vice versa. The tourism industry in relation to the main focus of instability (balance of payments, inflation, employment, investment, general consumption, weak economic structure, regional development) seems very positive. Stabilization effect of tourism is determined by the following goals: contribution to achieving and maintaining employment rates, reducing regional disparities in economic development, taking advantage of positive trends in the movement of tourism demand and tourist spending, etc. Unfortunately, the changes in the last decade led to negative effects. It has already been said that this region has never had features of active tourism, but its tourist value puts it in high correlation with a growing trend of individualization of foreign and domestic tourism demand.

\section{Conclusion}

For the purposes of the research, the authors conducted a survey in the area of Fruška Gora National Park. The starting points were assumptions, or more precisely, certain hypotheses and sub-hypotheses that should be proved or disproved. The assumption is that the active development of tourism in the area of Fruška Gora National Park may affect the development of its dispersion zone (in this case, Novi Sad), and there will also be tangible impacts on the business or economic development of a given area. In addition to these findings, the authors have used statistical and other information, as well as other available documents. Based on the research there is some information about the current development of sports and recreational tourism in Fruška Gora National Park. This is potentially the most important aspect of tourism trends in this area because of all the conditions, but not the only one. Therefore, the present study included mostly sports and leisure tourists. Based on the analysis of survey data confirmed the hypothesis $(\mathrm{H})$ in the part that speaks to large-scale tourism development lead to an improvement in the overall regional economic and business development. For now, this influence is minimal, although it is established that there is interest in the development of certain types of activities in Fruška Gora National Park, where all adequate conditions for their popularization have been provided. The visitors who were surveyed were dissatisfied with the accommodation, the quality of roads and signs. Unfortunately, the percentage of those dissatisfied varied in the ratio of $94.5 \%$ linking all the surveyed structures. The respondents were also asked about the disadvantages that need to be removed in the near future or at least mitigated to a certain extent, and these deficiencies were related to the marked trails, thematic maps, guides, transportation equipment and rental equipment, service stations and stops. In all these segments of supply that are essential for the development of sport and recreation great disadvantages are noticed, ranging from the highest percentage of employees in the hospitality industry, and slightly lower in travel intermediary activities. It could also be inferred that the percentage of investments and investment funds had a low priority in other industries, in which tourism is correlated, and this can be seen in the fact that tourism constantly invests its funds in its own development. It is important to emphasize that there are minimal effects of internal tourism in Vojvodina. Given that tourism development can be viewed as a planned, conscious and continuous activity (Riera-Font, 2000), then the development of tourism in Fruška Gora National Park is nothing more than the guiding of spatial distribution of relevant investment or corresponding spatial structure in which or with which there will be sports and recreational tourism in Fruška Gora National Park. Bearing all this in mind, we might be able to agree that modern tourism development, in general, approaches the economic and social planning, although this is not an easy task and requires a completely continuous research. The present level of development of tourist infrastructure networks and recreational and other facilities in Fruška Gora National Park, gen- 
erally speaking, is not in accordance with the possibilities that this national park can give. The existing programmes and facilities do not provide developed forms of tourism supply. Unfortunately, this leads to the conclusion that, generally speaking, the current promotion of Fruška Gora National Park is not present enough (Vujko, Plavša, 2010; Vujko, 2011; Vujko, 2012; Vujko, Plavša, 2014). When resources are concerned, the most important issue for tourism would be to determine the location of paths, their mapping, determination of their carrying capacity (Papageorgiou, Brotherton, 1999; Prato, 2001, 2009), evaluation and hierarchisation of resources according to their value and importance of tourism when it comes to recreation (resource of international, national, regional or local significance), (Stanev, 1976; Ritchie, Crouch, 2000). In line with global trends, it is important to apply the positive experiences of those who for a long time have been dealing with sports and recreational tourism and its importance for the development of regional tourism. All basic outputs of the current state of tourism business must be within the framework of a very serious effort to integrate tourism into broader economic trends and processes, with a strong systematic and stimulating social support, much higher than now. Starting from the experience of the past development and tourism, as well as from some of the essential elements of development, it can be confidently argued that tourism (domestic and foreign) has developed strongly, not only as an economic activity, but it had a certain impact on the overall economic flows. A large part of these implications undoubtedly reflected the positive trends in the national economy (balance of payments, employment, balanced regional development), and the negative consequences of (ineffective investment, low productivity of factors of production, endangering the natural resources and ecological balance), but they did not affect the development and stability of the overall economy of the country. These positive and negative implications occurred within extensive conditions, spontaneous, and not sufficiently planned tourism development. The factor which depends mostly on the further development of tourism is investing in the development of tourism. This area of investment incentives in supply should be subordinated to removing the disparities and limits - raising the qualitative level of supply and raising the reproductive capabilities of the tourism industry as repair complex. The transfer from accumulation from other industries and areas of tourism development on the basis of the so-called foreign interest is complicated by the strong short-term interests. The long-term economic interest of the economy beyond tourism to invest in its development is to increase the incomebased expansion of the market, creating a reproduc- tive unit, a reduction of some specific types of costs or raise the productivity of factors of production. Stabilization goals are focused not only on further economic growth, but also on the quality of that growth. Such a development can not rely only on new investment and employment, but should devote more attention to the productivity of factors of production and economic efficiency and economic relations with foreign countries. Qualitative changes are not possible without a change in the sources of economic growth. Tourism development in addition to its contribution to faster economic growth causes qualitative changes in other sectors. Reaching the right position in the tourism market in Europe and elsewhere is very difficult especially in the time of political and economic instability in the country. By the number of beds, number of visits and overnight stays (Gajić, 2010; Gajić and Ivkov, 2010), Vojvodina is still at the level of the 1960s or 1970s. It is often said that the right way to achieve success in tourism and move closer to Europe is to review the status of the past, learn from experience, create positive elements and eliminate limiting factors.

\section{References}

Andereck, K.L., Nyaupane, G.P. 2011. Exploring the nature of tourism and quality of life perceptions among residents. Journal of Travel Research 50, 248-260.

Barnett, P. 2004. Networking and partnerships in destination and development management, Collection of papers, ATLAS, 1, 11-21, Naples, Italy.

Besana, A., Bagnasco, M.A. 2014. Rethinking Tourism in Macroeconomics.

Blake, A., Sinclair, M.T., Campos Soria, J.A. 2006. Tourism productivity: Evidence from the United Kingdom. Annals of Tourism Research 33,4, 1099-1120.

Bramwell, B. 2011. Governance, the state and sustainable tourism: a political economy approach. Journal of Sustainable Tourism 19, 4/5, 459-477.

Cutumisu, N., Cottrell, S. 2004. Images of a sustainable tourism development strategy in WWF Pan Parks: Comparison between a Swedish and Romanian National Park. Collection of papers, ATLAS, 1,1, 189-203, Naples, Italy.

Downward, P., Lumsdon, L., Weston, R. 2009. Visitor Expenditure: The Case of Cycle Recreation and Tourism. Journal of Sport \& Tourism 14,1, 25-42, Routledge, London.

Hayward, P. 2001. Leisure and Tourism, Heinemann GNVQ Intermediate, Heineman, Oxford.

Hudson, S. 2003. Sport and adventure tourism, The Haworth Press, Inc., Binghamton.

Gajić, T., Ivkov, A. 2010. Possibilities and problems of tourist sector in employment stimulation on the territory of Vojvodina”. Revista de Turism 10, 32-41. 
Gajić, T. 2010. Human Resources as a Factor and Problem of Quality in Tourist Sector, Comminications in Dependability and quality Management. An International Journal 13,2, 50-60, Čačak, Serbia.

Hohl, A. E., Tisdell, Cl. A. 1995. Peripheral tourism development and management. Annals of Tourism Research 22,3, 517-534.

King, J., Slesser, M. 1995. Prospects for sustainable development: The significance of population growth. Population and Environment 16, 6, 487-505.

Lee, C.C., Chang, C.P. 2008. Tourism Development and Economic Growth: A Closer Look at Panels. Tourism Management 29, 180-192.

Mihalic, T. 2000. Environmental management of a tourist destination. A factor of tourism competitiveness. Tourism Management 21, 65-78.

Matthew, L. 2009. Reinventing the Wheel: A Definitional Discussion of Bicycle Tourism. Journal of Sport \& Tourism 14, 1, 5-23, Routledge, London.

Morakabati, Y., Fletcher, J., Prideaux, B. 2012. Tourism development in a difficult environment: a study of consumer attitudes, travel risk perceptions and the termination of demand. Tourism Economics 18, 5, 953-969.

Nunkoo, R., Smith, S.L.J. 2013. Political economy of tourism: Trust in government actors, political support, and their determinants. Tourism management 36, 120-132.

Nunkoo, R., Ramkissoon, H. 2011. Developing a community support model for tourism. Annals of Tourism Research 38, 3, 964-988.

Nunkoo, R., Ramkissoon, H. 2012. Power, trust, social exchange and community support. Annals of Tourism Research 39,3, 997-1023.

Nunkoo, R., Gursoy, D. 2012. Residents' support for tourism: an Identity perspective. Annals of Tourism Research 39,1, 243-268.

Papageorgiou, K., Brotherton, I. 1999. A management planning framework based on ecological, perceptual and economic carrying capacity: the case study of Vikos-Aoos National Park, Greece. Journal of Environmental Management 56, 271-284.

Prato, T. 2001. Modeling carrying capacity for national parks. Ecological Economics 39, 321-331.

Prato, T. 2009. Fuzzy adaptive management of social and ecological carrying capacities for protected areas. Journal of Environmental Management 90, 2551-2557.

Riera-Font, A. 2000. Mass tourism and the demand for protected natural areas: A travel cost approach.
Journal of Environmental Economics and Management 39, 97-116.

Ritchie, B.W., Hall, C.M. 1999. Bicycle tourism and regional development: A New Zealand case study. Anatolia - An international journal of tourism and hospitality research 10,2, 89-112.

Ritchie, J.R.B., Crouch, G.I. 200o. The competitive destination: A sustainability perspective. Tourism Management 21, 1-7.

Sterrer, W. 1993. Human economics: A non-human perspective. Ecological Economics 7,3, 183-202.

Stanev, P. 1976. Hermful ecological concequences of the development of the tourist industry and their prevention. UN-ECE, New York

Standeven, J., Knop, P., 1999. Sport Tourism. Human Kinetics, USA

Torkildsen, G. 2005. Leisure and recreation management (5th edn). Abingdon: Routledge.

Vujko, A., Plavša, J. 2010. Netvorking of Fruška gora lakes tourist offer through system of cyclepaths case study Sot, Bruje and Moharač. Scientific and technical journal in tourism Tourism 15,1, 1-10, Faculty of Science, Novi Sad.

Vujko, A. 2011. Fruška gora i Vršačke planine - sadašnje i buduće destinacije sportsko-rekreativnog turizma“, (Ph.D. thesis). PMF, Departman za geografiju, turizam i hotelijerstvo, Novi Sad. (In Serbian)

Vujko, A. 2012. Pozitivni aspekti razvoja biciklističkog turizma na turističkim destinacijama - studija slučaja Fruška gora. Tims Acta 6, 19-28. (In Serbian)

Vujko, A., Gajić, T. 2014. Opportunities for tourism development and cooperation in the region by improving the quality of supply - The "Danube Cycle Route "Case Study". Economic research 27, 1, 847860.

Vujko, A., Plavša, J. 2014. Evaluation of National Park Fruška Gora (Serbia) for sport and recreational tourism. Acta geographica Slovenica 54, 2, 321-334.

Vujko, A., Gajić, T. 2014. The gouverment policy impact on economic development of tourism. Agricultural economics 61, 3, 789-804.

Van Den Bergh, J.C.J.M. 1993. A framework for modeling economy-environment-development relationships based on dynamic carrying capacity and sustainable development feedback". Environmental Resources and Economics 3,4, 395-412.

Weed M. 2008. Sport tourism experience. Journal of Sport and tourism 13, 1-4, Routledge, London.

Weed, M., Bull, C. 2004. Sports tourism: participants, policy and providers. Oxford: Elsevier Butterworth-Heinemann. 